\title{
DUKUNGAN KELUARGA DAN KEPATUHAN DIET LANSIA PENDERITA HIPERTENSI DI WILAYAH KERJA PUSKESMAS TUMPAAN
}

\author{
[FAMILY SUPPORT AND ADVANCED DIET COMPLIANCE AGE OF \\ HYPERTENSION PATIENTS] \\ Alfany Natalia Torar, Semuel Tambuwun, Herlina Memah, Yourisna Pasambo \\ Jurusan Keperawatan Poltekkes Kemenkes Manado \\ e-mail : Poltekkes Kemenkes Manado \\ tambuwunsemuel@gmail.com
}

DOI : 10.47718/jpd.v8i01.903

ABSTRAK

\begin{abstract}
Latar Belakang Data yang diperoleh dari wilayah kerja puskesmas Tumpaan ditemukan Hipertensi pada lansia merupakan penyakit menonjol pertama pada rentang bulan Januari-Desember 2017 sebanyak 465 penderita dan tahun 2018 jumlah penderita sebanyak 510. Berdasarkan studi pendahuluan lansia memiliki tekanan darah tinggi mengatakan tekanan darahnya sering meningkat karena tidak patuh menjalankan diet. Kurangnya dukungan anggota keluarga dapat mempengaruhi perilaku kepatuhan pelaksanaan diet hipertensi. Tujuan penelitian ini adalah mengetahui Hubungan Dukungan Keluarga dengan Kepatuhan Diet Lansia Penderita Hipertensi di Wilayah Kerja Puskesmas Tumpaan Daerah Pesisir Pantai dan Daerah Pegunungan. Metode penelitian ini adalah Analitik Korelasi dengan rancangan cross sectional. Populasi dalam penelitian ini adalah lansia dengan Hipertensi. Teknik pengambilan sampel menggunakan proportional random sampling dengan jumlah 84 orang yang dibagi menjadi 42 orang didaerah pesisir dan 42 orang didaerah pegunungan dan teknik analisis data menggunakan uji Chi Square. Hasil Penelitian menunjukkan didaerah pesisir pantai 31\% responden dengan dukungan keluarga baik, $40 \%$ responden dukungan keluarga cukup dan $29 \%$ responden dukungan keluarga kurang sedangkan $52 \%$ menunjukkan kepatuhan diet patuh dan $48 \%$ kepatuhan diet tidak patuh. Hasil uji statistik chi-square (pearson chi-square) didapatkan nilai P-value sebesar 0,008, artinya $\mathrm{P}$-value $<0.05$. Hasil penelitian didaerah pegunungan $40 \%$ responden dengan dukungan keluarga baik, 31\% responden dukungan keluarga cukup dan $29 \%$ responden dukungan keluarga kurang, 57\% menunjukkan kepatuhan diet patuh dan $43 \%$ kepatuhan diet tidak patuh. Hasil uji statistik chi-square (pearson chi-square) didapatkan nilai P-value sebesar 0,021, artinya P-value
\end{abstract}


$<0.05$. Kesimpulan dari penelitian ini adalah ada hubungan dukungan keluarga dengan kepatuhan diet lansia penderita hipertensi baik didaerah pesisir pantai dan didaerah pegunungan.

Kata Kunci: dukungan keluarga, kepatuhan diet hipertensi

ABSTRACT
Introduction Data obtained from the working area of Puskesmas Tumpaan found that hypertension in the elderly was the first prominent disease in the range of January-December 2017, as many as 465 patients and in 2018 the number of patients was 510 . Based on preliminary studies of elderly people with high blood pressure, said their blood pressure often increases because they do not adhere to a diet. Lack of support from family members can influence the compliance behavior of implementing a hypertension diet. The purpose of this study is to find out the relationship between family support and adherence to the diet of elderly people with hypertension in the work area of the Puskesmas Tumpaan in the coastal areas and and mountain areas. This type of research is Correlation Analytic with cross sectional design. The population in this study is the elderly with hypertension. The sampling technique uses proportional random sampling with a total of 84 people divided into 42 people in coastal areas and 42 people in mountain areas and data analysis techniques using the Chi Square test. The results showed that in the coastal areas $31 \%$ of respondents with good family support, $40 \%$ of respondents had adequate family support and $29 \%$ of respondents had less family support while $52 \%$ showed adherent diet adherence and $48 \%$ adherence to non-adherent diet. The results of the chi-square statistical test (Pearson chi-square) obtained a P-value of 0.008 , meaning that the P-value $<0.05$. The results of the study in the mountain areas of $40 \%$ of respondents with good family support, $31 \%$ of respondents with adequate family support and $29 \%$ of respondents with less family support, $57 \%$ showed adherent diet adherence and $43 \%$ of adherent diet adherence. The results of the chi-square statistical test (Pearson chi-square) obtained a P-value of 0.021 , meaning that the $P$-value $<0.05$. The conclusion of this study is that there is a relationship of family support with adherence to the diet of elderly patients with hypertension in both coastal and mountain areas.

Key words: occupational disease and accidents, head nurse. 


\section{PENDAHULUAN}

Bertambahnya umur, fungsi fisiologis mengalami penurunan akibat proses penuaan sehingga penyakit tidak menular banyak muncul pada lanjut usia. Masalah degeneratif juga menurunkan daya tahan tubuh sehingga rentan terkena infeksi penyakit menular. Hasil Riskesdas 2013, penyakit terbanyak pada lanjut usia adalah Penyakit Tidak Menular (PTM) antara lain hipertensi, artritis, stroke, Penyakit Paru Obstruktif Kronik (PPOK) dan Diabetes Mellitus (DM) (Infodatin, 2016). Salah satunya penyakit atau masalah kesehatan yang paling tinggi dan menempati urutan pertama pada masalah kesehatan lansia di Indonesia yaitu penyakit hipertensi sebesar 57,6\% (Kemenkes RI, 2016).

Di wilayah kerja Puskesmas Tumpaan terdapat 10 desa yang terdiri dari 6 desa yang berada di pesisir pantai dan 4 desa yang berada di daerah pegunungan. Data yang diperoleh dari wilayah kerja puskesmas Tumpaan ditemukan bahwa Hipertensi pada lansia merupakan penyakit menonjol pertama pada rentang bulan Januari-Desember 2017 sebanyak 465 penderita dan pada tahun 2018 jumlah penderita sebanyak 510 dengan masing-masing 310 yang berada di daerah pesisir pantai dan 200 berada di daerah pegunungan.

Status sehat sakit para anggota keluarga saling mempengaruhi satu sama lain. Suatu penyakit dalam keluarga mempengaruhi status kesehatan anggota keluarga. Keluarga merupakan jaringan yang mempunyai hubungan erat dan bersifat mandiri, dimana masalah-masalah seorang individu dapat mempengaruhi anggota keluarga yang lain dan seluruh system. Keluarga memiliki pengaruh yang penting terhadap pembentukan identitas seorang individu dan perasaan harga diri. Keluarga memainkan suatu peran yang 
bersifat mendukung selama masa penyembuhan dan pemulihan klien.

Dukungan keluarga diperlukan untuk menambah rasa percaya diri dan motivasi untuk menghadapi masalah dan meningkatkan kepatuhan diet hipertensi. Peran keluarga harus dilibatkan dalam pemenuhan kebutuhan, serta mendukung dalam kepatuhan untuk mengurangi resiko kekambuhan dan komplikasi. Keluarga dapat membantu dalam perawatan hipertensi dengan mengatur pola makan yang sehat, mengajak berolahraga, menemani dan meningkatkan pemeriksaan secara rutin dalam meriksaan tekanan darah (Susriyanti, 2014), serta mengurangi asupan garam dan lemak tinggi . disamping itu, perlunya meningkatkan makan buah dan sayur (Triyanto, 2010).

Berdasarkan hasil studi pendahuluan pada tanggal 10 januari 2019 di Puskesmas Tumpaan Kecamatan Tumpaan Kabupaten Minahasa Selatan, di dapatkan 6 dari 8 lansia memiliki tekanan darah tinggi mengatakan tekanan darahnya sering meningkat kerena tidak patuh menjalankan diet. Berdasarkan hal tersebut, kepatuhan diet sangat berpengaruh terhadap peningkatan tekanan darah pada lansia penderita hipertensi, dalam penelitian yang dilakukan oleh Miyusliani dan Yunita (2011) menunjukkan penderita dengan usia lebih dari 55 tahun lebih beresiko 95\% untuk tidak patuh terhadap diet hipertensi dibanding dengan penderita usia kurang dari 55 tahun, dan dukungan keluarga sangat berperan penting dalam penatalaksanaan diet pada lansia penderita hipertensi, maka bedasarkan uraian di atas penulis tertarik melakukan penelitian mengenai hubungan dukungan keluarga dengan kepatuhan diet lansia penderita hipertensi di wilayah kerja Puskesmas Tumpaan Kecamatan Tumpaan Kabupaten Minahasa Selatan. Tujuan 


\section{METODE}

PENELITIAN
HASIL DAN

PEMBAHASAN penelitian ini adalah mengetahui hubungan dukungan keluarga dengan kepatuhan diet lansia penderita hipertensi di Wilayah Kerja Puskesmas Tumpaan Jenis penelitian yang digunakan adalah analitik korelasi dengan pendekatan cross sectional artinya obyek diobservasi satu kali saja dan pengukuran menggunakan variabel independen dan dependen dilakukan pada saat penelitian. Hal ini dilakukan untuk mengetahui hubungan dukungan keluarga dengan kepatuhan diet lansia penderita hipertensi. Penelitian ini dilakukan pada tanggal 5-12 Juli 2019. Variabel independen adalah dukungan keluarga, variabel dependen adalah kepatuhan diet lansia penderita hipertensi.

Diagram 1. Distribusi Responden Berdasarkan Tekanan Darah Lansia Daerah Pesisir Pantai

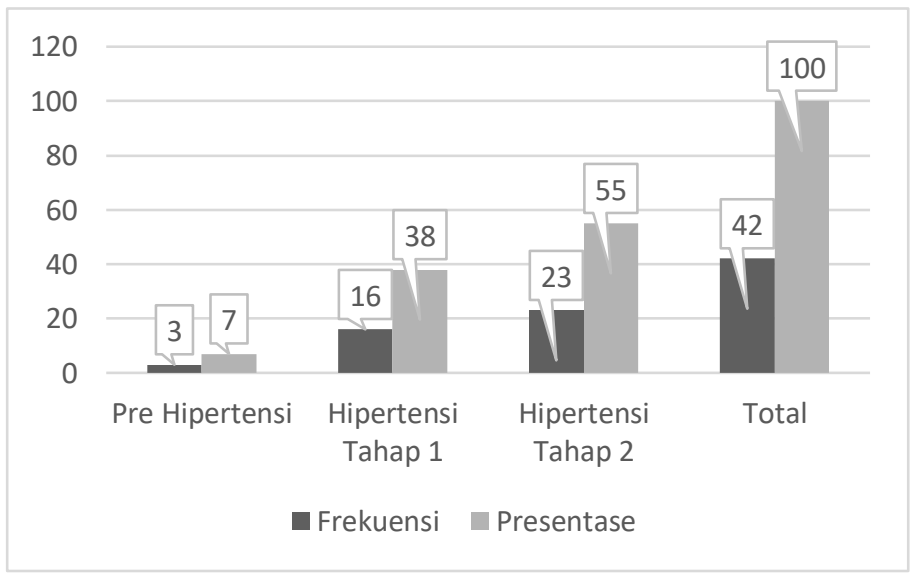


Volume 08 No.01, Juli 2020 e-ISSN : 26559382 p-ISSN : 22524843

Diagram 2. Distribusi Responden Berdasarkan Tekanan Darah Lansia Daerah Pegunungan

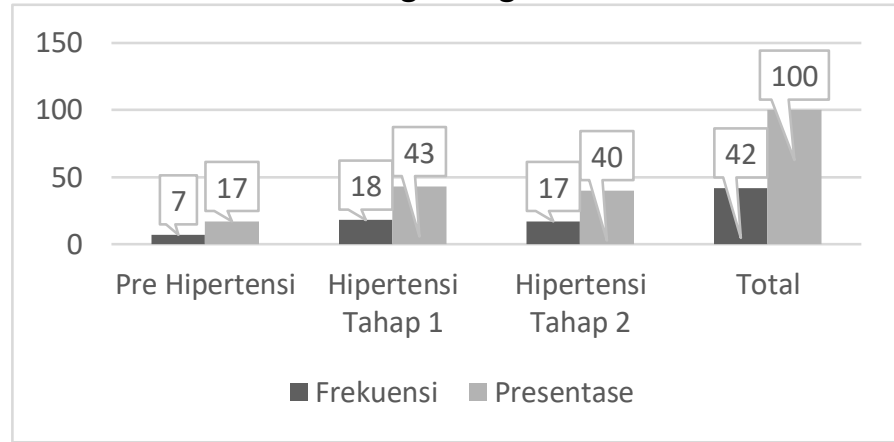

Diagram 3. Dukungan Keluarga Daerah Pesisir Pantai

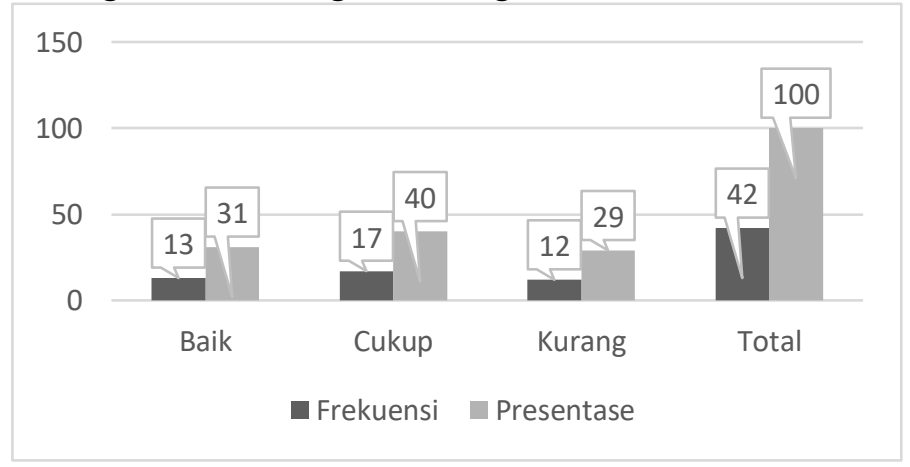

Diagram 4. Dukungan Keluarga Daerah Pegunungan

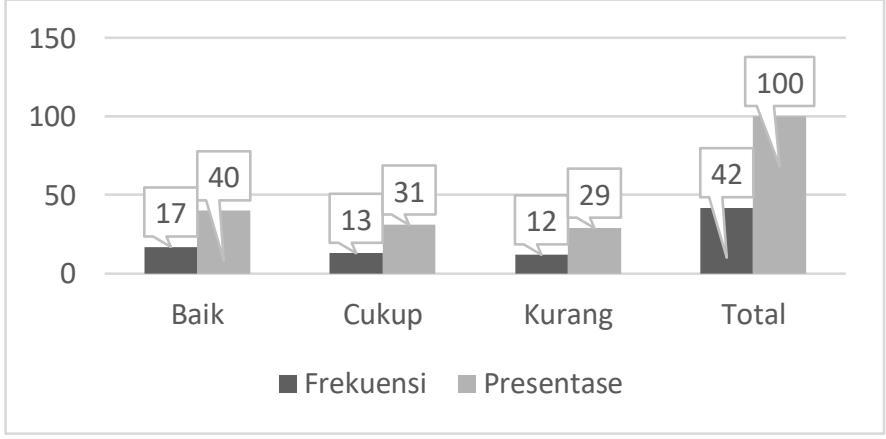


Diagram 5. Kepatuhan Diet Lansia Hipertensi Daerah Pesisir Pantai

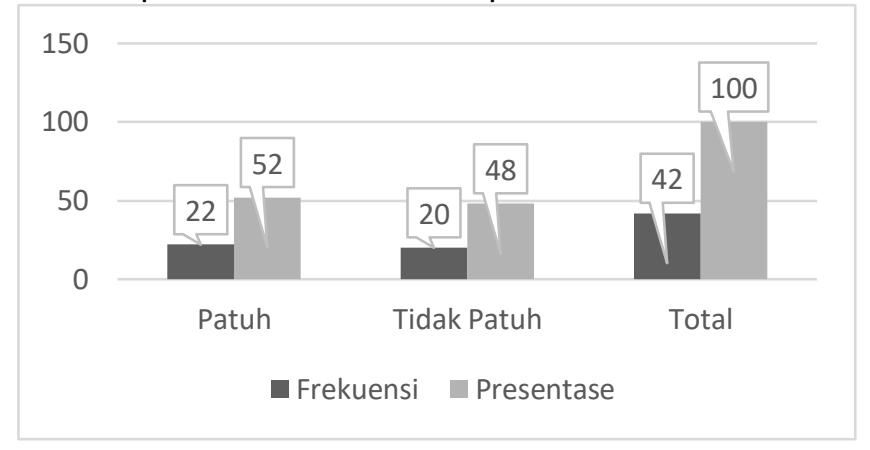

Diagram 6. Kepatuhan Diet Lansia Hipertensi Daerah Pegunungan

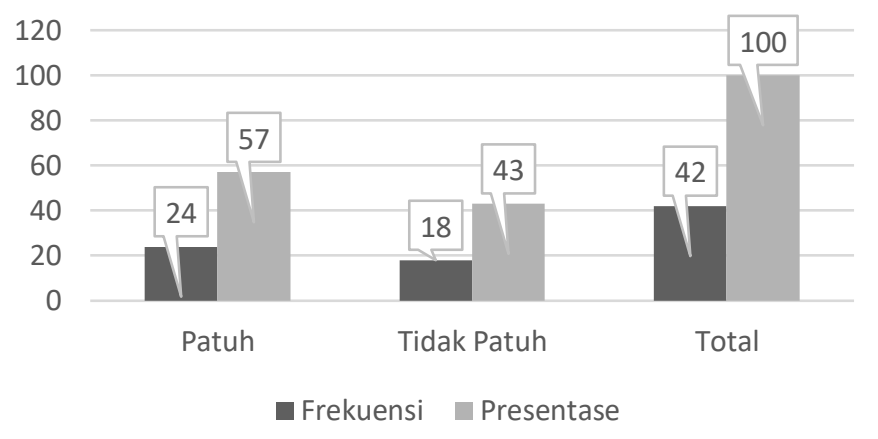

Tabel 1. Hubungan Dukungan Keluarga Dengan Kepatuhan Diet Lansia Penderita Hipertensi di Wilayah Kerja Puskesmas Tumpaan di Daerah Pesisir Pantai

\begin{tabular}{|c|c|c|c|c|c|c|c|}
\hline \multirow{4}{*}{$\begin{array}{l}\text { Dukungan } \\
\text { Keluarga }\end{array}$} & \multicolumn{4}{|c|}{ Kepatuhan Diet Lansia Penderita } & \multirow{2}{*}{\multicolumn{2}{|c|}{ Total }} & \multirow{4}{*}{$\begin{array}{c}\text { P- } \\
\text { Value }\end{array}$} \\
\hline & \multicolumn{4}{|c|}{ Hipertensi } & & & \\
\hline & \multicolumn{2}{|c|}{ Tidak Patuh } & \multicolumn{2}{|c|}{ Patuh } & \multirow[b]{2}{*}{$\mathrm{N}$} & \multirow[b]{2}{*}{$\%$} & \\
\hline & $\mathrm{N}$ & $\%$ & $\mathrm{~N}$ & $\%$ & & & \\
\hline Kurang & 10 & $83.3 \%$ & 2 & $16.7 \%$ & 12 & $100 \%$ & \multirow{4}{*}{0.008} \\
\hline Cukup & 7 & $41.2 \%$ & 10 & $58.8 \%$ & 17 & $100 \%$ & \\
\hline Baik & 3 & $23.1 \%$ & 10 & $76.9 \%$ & 13 & $100 \%$ & \\
\hline Total & 20 & $47.6 \%$ & 22 & $52.4 \%$ & 42 & $100 \%$ & \\
\hline
\end{tabular}


Tabel 1. Hubungan Dukungan Keluarga Dengan Kepatuhan Diet Lansia Penderita Hipertensi di Wilayah Kerja Puskesmas Tumpaan di Daerah Pegunungan

\begin{tabular}{|c|c|c|c|c|c|c|c|}
\hline \multirow{4}{*}{$\begin{array}{l}\text { Dukungan } \\
\text { Keluarga }\end{array}$} & \multicolumn{6}{|c|}{ Kepatuhan Diet Lansia Penderita } & \multirow{4}{*}{$\begin{array}{c}P \text { - } \\
\text { Value }\end{array}$} \\
\hline & \multicolumn{4}{|c|}{ Hipertensi } & \multirow{2}{*}{\multicolumn{2}{|c|}{ Total }} & \\
\hline & \multicolumn{2}{|c|}{ Tidak Patuh } & \multicolumn{2}{|c|}{ Patuh } & & & \\
\hline & $\mathrm{N}$ & $\%$ & $\mathrm{~N}$ & $\%$ & $\mathrm{~N}$ & $\%$ & \\
\hline Kurang & 9 & $75.0 \%$ & 3 & $25.0 \%$ & 12 & $100 \%$ & \multirow{4}{*}{0.021} \\
\hline Cukup & 5 & $38.5 \%$ & 8 & $61.5 \%$ & 13 & $100 \%$ & \\
\hline Baik & 4 & $23.5 \%$ & 13 & $76.5 \%$ & 17 & $100 \%$ & \\
\hline Total & 18 & $42.9 \%$ & 24 & $57.1 \%$ & 42 & $100 \%$ & \\
\hline
\end{tabular}

Hasil yang didapatkan pada diagram 3 menunjukkan bahwa dukungan keluarga di daerah pesisir pantai paling banyak cukup berjumlah 17 responden (40\%) dan paling sedikit dukungan keluarga kurang berjumlah 12 responden (29\%). Dan Hasil yang didapatkan pada diagram 12 menunjukkan bahwa dukungan keluarga di daerah pegunungan yang paling banyak yaitu baik berjumlah 17 responden (40\%) dan paling sedikit dukungan keluarga kurang berjumlah 12 responden (29\%).

Dukungan keluarga adalah sikap, tindakan dan penerimaan keluarga terhadap keluarga yang sakit ataupun keluarga yang sehat. Anggota keluarga memandang bahwa orang yang bersifat mendukung selalu siap memberikan pertolongan dan bantuan jika diperlukan, Friedman (1998) dalam Akhmadi (2009). Peran keluarga harus dilibatkan dalam pemenuhan kebutuhan, serta mendukung dalam kepatuhan untuk mengurangi resiko kekambuhan dan komplikasi. Keluarga dapat membantu dalam perawatan hipertensi dengan mengatur pola makan yang sehat, mengajak berolahraga, menemani dan meningkatkan pemeriksaan secara rutin dalam meriksaan tekanan darah (Susriyanti, 2014), 
Dukungan keluarga merupakan hal yang sangat penting untuk seseorang.

Adanya dukungan keluarga terhadap lansia dapat menyebabkan ketenangan batin dan perasaan yang senang dalam diri lansia. Selain itu dengan adanya dukungan keluarga berdampak pada kemudahan lansia untuk melakukan diet hipertensi. Keluarga juga mempunyai peran utama dalam memberi dorongan kepada lansia sebelum pihak lain memberi dukungan. dukungan informasi merupakan factor yang dominan terhadap perilaku lansia dalam pengendalian hipertensi. Dukungan keluarga sangat penting dalam meningkatkan derajat kesehatan lansia.

Berdasarkan hasil pengolahan data pada diagram 5 didapatkan bahwa kepatuhan diet pada lansia penderita hipertensi di pesisir pantai lebih banyak patuh berjumlah 22 responden (52\%) dan tidak patuh berjumlah 20 responden (48\%). Hasil pengolahan data pada diagram 6 didapatkan bahwa kepatuhan diet pada lansia penderita hipertensi di pegunungan lebih banyak patuh berjumlah 24 responden (57\%) dan tidak patuh berjumlah 18 responden (43\%).

Hubungan Dukungan Keluarga dengan Kepatuhan Diet Lansia Penderita Hipertensi di Wilayah Kerja Puskesmas Tumpaan Daerah Pesisir Pantai. Dari hasil tabulasi analisis persilangan menujukaan responden lansia hipertensi yang mendapat dukungan keluarga baik sebagian besar memiliki kepatuhan baik dalam kepatuhan diet hipertensi sebanyak 10 responden (76.9\%). Responden yang mendapatkan dukungan keluarga cukup sebagian besar memiliki kepatuhan baik dalam menjalankan kepatuhan diet hipertensi sebanyak 10 responden (58.8\%). Sedangkan responden dengan dukungan keluarga kurang memiliki kepatuhan baik sebanyak 2 responden (16.7\%). Hasil dari analisa data dengan uji statistik chi-square (pearson chi-square) 
dengan SPSS versi 25 didapatkan nilai P-value sebesar 0,008 artinya P-value < 0.05, Ho ditolak dan Ha diterima. Hal ini menunjukkan bahwa ada hubungan yang bermakna antara dukungan keluarga dengan kepatuhan diet lansia penderita hipertensi di wilayah kerja Puskesmas Tumpaan daerah pesisir pantai.

Dalam karakteristik responden penelitian, responden perempuan lebih banyak sebanyak 32 responden (76\%). Menurut umur responden dengan umur 60-70 tahun sebanyak 36 responden (86\%). Pendidikan SMP paling dominan sebanyak 17 responden (40\%). Pekerjaan lebih banyak responden yang tidak bekerja sebanyak 31 responden (74\%). Dan berdasrakan hasil pengukuran tekanan darah hipertensi tahap 2 menjadi paling banyak yaitu sebanyak 23 responden (55\%). Keluarga merupakan sentral pelayanan keperawatan. intervensi yang dilakukan pada keluarga merupakan hal penting untuk pemenuhan kebutuhan individu, adanya hubungan yang kuat antara keluarga dan status kesehatan setiap anggota keluarga, sangat memerlukan peran keluarga pada saat menghadapi masalah yang terjadi pada keluarga (Achjar, 2010). Hal ini sesuai dengan teori Feurerstein et al (1986) dalam Niven (2013) yang menyatakan keluarga dapat menjadi faktor yang mempengaruhi dalam menentukan keyakinan dan nilai kesehatan individu serta dapat menentukan tentang program pengobatan yang diterima. Dalam penelitian ini didapatkan banyak keluarga yang membiarkan lansia tinggal dirumah sendiri tanpa adanya anggota keluarga yang menjaga sehingga keluarga kurang memperhatikan makanan yang dikonsumsi pasien lansia hipertensi sehinggan masih terdapat responden dengan kategori dukungan keluarga kurang dan tidak patuh menjalankan diet hipertensi sebanyak 10 responden (83.3\%). 
Hubungan keluarga yang harmonis akan memberikan ketenangan dan mengurangi beban yang dirasakan karena pada saat seseorang menghadapi tekanan dan kesulitan hidup seseorang memerlukan orang lain untuk berbagi, mendengarkan atau mencari informasi yang relevan. Sehingga dukungan keluarga dalam bentuk dukungan informasi, dukungan emosional, dukungan penghargaan dan dukungan instrumental akan membuat pasien hipertensi akan memiliki kepatuhan yang baik dalam pengendalian hipertensi Friedman (2010).

Hasil penelitian ini sejalan dengan penelitian yang dilakukan oleh Herlinah Lily, dkk (2013), menunjukan ada hubungan antara dukungan emosional, dukungan penghargaan, informasi, dan instrumental dengan perilaku lansia dalam pengendalian hipertensi dengan nilai $(p<0,05)$. Hasil penelitian ini sejalan dengan penelitian Fitri (2012) yang menunjukan ada hubungan antara dukungan keluarga dengan kepatuhan diet rendah garam dengan nilai $p=0,017(p<0,05)$. Hasil penelitian tersebut mendukung hasil penelitian ini dimana dukungan keluarga memiliki hubungan dengan kepatuhan diet lansia penderita hipertensi di daerah pesisir pantai. Dalam hal ini membuktikan bahwa semakin baik dukungan keluarga maka semakin tinggi tingkat kepatuhan lansia dalam menjalankan diet hipertensi.

Dari hasil tabulasi analisis persilangan menunjukan responden lansia hipertensi yang mendapat dukungan keluarga baik sebagian besar memiliki kepatuhan baik dalam kepatuhan diet hipertensi sebanyak 13 responden (76,5\%). Responden yang mendapat dukungan keluarga cukup sebagain besar memiliki kepatuhan dalam melaksanakan kepatuhan diet hipertensi sebanyak 8 responden (61.5\%). Sedangkan responden yang mendapat dukungan keluarga kurang sebagian memiliki tingkat kepatuhan sebanyak 3 responden 
(25.0\%). Hasil dari analisa data dengan uji statistik chi-square (pearson chisquare) dengan SPSS versi 25 didapatkan nilai P-value sebesar 0,021 artinya Pvalue $<0.05$, Ho ditolak dan Ha diterima. Hal ini menunjukkan bahwa ada hubungan yang bermakna antara dukungan keluarga dengan kepatuhan diet lansia penderita hipertnesi di wilayah kerja Puskesmas Tumpaan daerah pegunungan.

Dalam karakteristik responden penelitian, responden perempuan lebih banyak sebanyak 29 responden (69\%). Menurut umur responden dengan umur 60-74 tahun sebanyak 31 responden (74\%). Pendidikan SMA paling dominan sebanyak 14 reponden (33\%). Pekerjaan lebih banyak responden yang tidak bekerja sebanyak 34 responden (81\%). Dan berdasarakan hasil pengukuran tekanan darah hipertensi tahap 1 menjadi paling banyak yaitu sebanyak 18 responden (43\%). Dalam menghadapi penyakit yang diderita, pasien lansia hipertensi membutuhkan dukungan keluarga. Dukungan keluarga yang diberikan keluarga akan membuat pasien merasa berharga karena masih ada orang yang mencintai dan memperhatikan. Saat dilakukan penelitian didapatkan keluarga lansia didaerah pegunungan sering memperhatikan diet hipertensi pada lansia karena sebagian keluarga mengatakan orang tua sangat dihormati dan dikasihi dalam keluarga sehingga makanan dan pengobatan dari lansia yang menderita hipertensi sangat penting untuk diperhatikan oleh keluarga. Hubungan keluarga yang harmonis akan memberikan ketenangan dan mengurangi beban yang dirasakan karena pada saat seseorang menghadapi tekanan dan kesulitan hidup seseorang memerlukan orang lain untuk berbagi, mendengarkan atau mencari informasi yang relevan. Sehingga dukungan keluarga dalam bentuk dukungan informasi, dukungan emosional, dukungan penghargaan dan dukungan instrumental 
akan membuat pasien hipertensi akan memiliki kepatuhan yang baik dalam pengendalian hipertensi Friedman (2010). Dalam hal ini membuktikan bahwa semakin baik dukungan keluarga maka semakin tinggi tingkat kepatuhan lansia dalam menjalankan diet hipertensi.

Menurut Kuntjoro (2005) menyatakan bahwa salah satu faktor yang mempengaruhi perilaku anggota keluarga adalah sejauh mana keluarga memberikan dukungan kepada anggota keluarga. Hasil penelitian ini juga menunjukan bahwa masih ada responden yang mendapat dukungan keluarga kurang akan tetapi memiliki kepatuhan yang baik sebanyak 3 responden (25.0\%). Hal tersebut sesuai dengan pendapat Wawan (2010) yang mengemukakan bahwa kepatuhan dibentuk melalui suatu proses dan didasari oleh adanya kesadaran dan sikap yang positif, dengan demikian bahwa semakin baik dukungan yang diberikan oleh keluarga responden lansia hipertensi maka akan semakin tinggi pula kepatuhan dalam menjalankan diet hipertensi. Hasil penelitian ini di dukung oleh penelitian Komaling, dkk (2015), menyimpulkan adanya hubungan dukungan keluarga dengan kepatuhan diet pada pasien hipertensi di daerah pegunungan.

KESIMPULAN

\section{DAFTAR}

PUSTAKA
Kesimpulan dalam penelitian ini adalah terdapat hubungan dukungan keluarga dengan kepatuhan diet lansia penderita hipertensi di Wilayah Kerja Puskesmas Tumpaan daerah pesisir pantai dan daerah pegunungan.

Achjar, K. A. H. (2010). Aplikasi Praktis Asuhan Keperawatan Keluarga. Jakarta: Sagung Seto.

Akhmadi.

(2009).

Dukungan

Keluarga.

From: http://repository.usu.ac.id/bitstrieam Diakses pada 8 febuari 2019.

Amelia, F., dan Sartika, R. A. D. 2015. Faktor-Faktor yang Berhubungan dengan Kepatuhan Diet DASHI pada Penderita Hipertensi Usia 30-65 
Tahun di Puskesmas Bojonggede Kabupaten Bogor Tahun 2015.

https://lib.ui.ac.id/detail?id=20411713\&lokasi=lokal Diakses pada $10 \mathrm{Juli}$ 2019.

Amin, H. N \& Kusuma, H. (2015). Aplikasi Asuhan Keperawatan Berdasarkan Diagnosa Medis dan Nanda Nic Noc. Jogjakarta : MediAction

Arikunto, S. (2006). Prosedur Penelitian Suatu Pendekatan Praktik. Jakarta: PT. Rineka Cipta.

Artikel Kementerian Kesehatan Republik Indonesia (2013). Populasi Lansia Diperkirakan Terus Meningkat Hingga Tahun 2020.www.depkes.go.id, http://www.depkes.go.id/pdf.php?id=13110002 diakses pada tanggal 26-01-2019.

Azizah, L. M. (2011). Keperawatan Lajut Usia. Yogyakarta : Graha Ilmu Badan Pusat Statistik. (2010). Statistik Penduduk Lanjut Usia Provinsi Sulawesi Utara 2010. Jakarta.

Badan Pusat Statistik. (2017). Jumlah Penduduk Kelompok Umur dan Jenis Kelamin di Kabupaten Minahasa Selatan Population by Age Group and Sex in Minahasa Selatan Regency 2017. From https://minselkab.bps .go.id diakses 5-02-2019.

Bawekes, M. W. (2014). Tingkat kemandirian kelompok lansia berbasis penerapan community healt nursing di Wilayah Kerja Puskesmas Ranomut Kecamatan Paal Dua Kota Manado. KTI tidak dipublikasikan. Perpustakaan Poltekkes Kemenkes Manado.

Devita. (2014). Hubungan pengetahuan dengan Kepatuhan lansia penderita hipertensi dalam pemenuhan diet hipertensi. Surakarta.Skripsi.Stikes Husada Surakarta.

Fitri, D. P. N., Yunie, A., dan Mamat, S. 2012. Hubungan Dukungan Keluarga dengan Kepatuhan Diet Rendah Garam dan Keteraturan Kontrol Tekanan Darah Pada Penderita Hipertensi di Poliklinik RSUD Tugu Rejo Semarang. 
https://www.e-jurnal.com/2013/10/hubungan-dukungan-keluargadengan.html Diakses pada 10 Juli 2019

Friedman, M. M., Bowden, V. R., \& Jones, E. G. (2010). Buku ajar Keperawatan Keluarga: Riset, teori, dan praktik, diterjemahkan oleh AA Nasution Edisi 5. Jakarta: EGC.

Herlinah Lily, Wiarsih, \& Etty Rekawati. (2013). Hubungan Dukungan Keluarga dengan Perilaku Lansia Dalam Pengendalian Hipertensi. Jurnal Keperawatan Komunitas. Volume 1, No. 2, November 2013; 108-115.

http://jurnalrespirologi.org/jurnal/April09/Dukungan\%20Keluarga.pdf Diakses pada 10 Juli 2019

Infodatin. (2016). Situasi Lanjut Usia (Lansia) di Indonesia. Jakarta : Pusat Data dan Informasi Kemenkes RI.

Jhonson, (2010). Keperawatan keluarga. Yogyakarta. Nuhu Medika. Kementrian Kesehatan RI. (2016). INFODATIN Pusat Data dan Informasi tentang Situasi Lansia (Lanjut Usia) di Indonesia. Jakarta Selatan. Pdf, (Online), (www.depkes.go.id/download.php?file.../infodatin/infodatin\%20lansia \%202016.pdf, diakses 24 -01-2019).

Kemenkes RI. (2017). Analisa Lansia Indonesia. Jakarta : Pusat Data dan Informasi Kemenkes RI

Komaling, H. Y., Girsang, O., dan Tololiu, T. 2015. Hubungan Dukungan Keluarga Dengan Kepatuhan Diet pada Pasien Hipertensi di Wilayah Kerja Puskesmas Tinoor. Buletin Sariputra Jurnal IImu-IImu Multidisiplin. Volume 5, No. 2, Juni 2015; 80-84.

http://jurnal.unsrittomohon.ac.id/index.php?journal=jurnalprint\&page=articl e\&op=view\&path\%5B\%5D=161 Diakses pada 10 Juli 2019

Kuntjoro. (2005). Sikap Dan Perilaku Dalam Keluarga. Jurnal Kesehatan Keluarga. http://www.e-psikologi.com/usia/htm. Diakses 31 juli 2019 


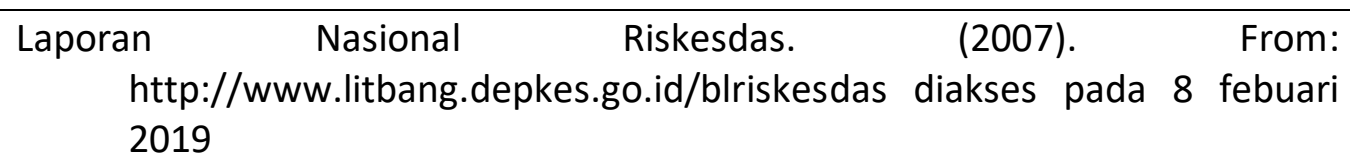

Miyusliani, S., dan Yunita, J. (2011). Faktor Resiko Yang Berpengaruh Terhadap Kepatuhan Diet Hipertensi. Pekanbaru: STIKES Hang Tuah. Jurnal Kesehatan Komunitas, Vol. 1, No. 3, November 2011.

Muhammadun. (2010). Hidup Bersama Hipertensi. Yogyakarta: In Books.

Novian, Arista. (2013). Faktor yang Berhubungan dengan Kepatuhan Diet Pasien Hipertensi, kesmas,Vol.9, No.1, Juli 2013, Hal 100-105.

Nugroho, W. 2008. Keperawatan Gerontik dan Geriatrik. Jakarta: Buku Kedokteran EGC.

Nursalam. (2013). Metode Penelitian Ilmu Keperawatan Pendekatan Praktis, Edisi 3. Jakarta: Salemba Medika.

Purnawan. (2010). Faktor yang mempengaruhi dukungan keluarga. From: http://repository.usu.ac.id/bitstream. Diakses pada 4 febuari 2019

Rasajati, Q. P., Raharjo, B. B., dan Ningrum, D. N. A. 2015. Faktor-faktor yang Berhubungan dengan Kepatuhan Pengobatan pada Penderita Hiperrtensi di Wilayah Kerja Puskesmas Kedungmundu Kota Semarang. Unnes Journal of Public Health. Volume 4, No. 3, Juli 2015; 16-23.

https://journal.unnes.ac.id/sju/index.php/ujph/article/view/6339 Diakses pada 10 Juli 2019.

Rosaline, Grachia. (2016). Gambaran fungsi keluarga dengan klien hipertensi di Desa Mundung I Kecamatan Tombatu Timur Kabupaten Minahasa Tenggara, p.13. KTI tidak dipublikasikan. Perpustakaan Poltekkes Kemenkes Manado.

Rusliafa, J., Amiruddin, R., dan Noor, N. (2014). Komparatif Kejadian Hipertensi Pada Wilayah Pesisir Pantai dan Pegunungan di Kota Kendari. Makassar: Skripsi Universitas Hasanuddin 
Setiadi, (2008). Konsep dan Proses Keperawatan Keluarga. Graha Ilmu. Yogyakarta.

Setiadi, (2013). Konsep dan Praktek Penulisan Riset Keperawatan. Edisi 2. Graha Ilmu. Yogyakarta.

Setiawati, S. (2006). Hubungan Asupan Zat Gizi Dengan Kejadian Hipertensi di Pulau Manado Tua Kecamatan Bunaken Kota Manado. Manado: Skripsi Universitas Sam Ratulangi

Sugiyono. (2007). Metode Penelitian Kunatitatif Kualitatif dan R\&D. Bandung: Alfabeta

Sunaryo, dkk. (2016). Asuhan Keperawatan Gerontik. Edisi I. Yogyakarta :ANDI

Susriyanti (2014). Hubungan Dukungan Keluarga dengan Perilaku Perawatan Hipertensi pada Lansia di Gamping Sleman Yogyakarta. From http://digilib.unisayogya.ac.id/483/1/naskah\%20publikasi.pdf. Diakses pada 6 febuari 2019

Triyanto, Endang. (2014). Pelayanan Keperawatan bagi Penderita Hipertensi Secara Terpadu. Yogyakarta: GRAHA ILMU.

Wawan. (2010). Teori Dan Pengukuran Pengetahuan Perilaku dan Sikap Manusia. Yogyakarta: Nuhu Medika.

Wulandari, Yeki Susilo dan Ari. (2011). Cara jitu mengatasi hipertensi. C. V. ANDI OFFEST. Yogyakarta. 